\title{
Globalization and Death: Search of Monoculture in Cultural Diversity
}

\author{
Tatiana Pavlovna Vaganova \\ Ural Federal University \\ Ural Humanities Institute \\ Yekaterinburg, Russian Federation Vaganova.owl@yandex.ru
}

\begin{abstract}
The values of cultures are so different that it is difficult to find the basis for the formation of a monoculture in the context of globalization. The study of the phenomenon of death will bring closer to solving the problem of finding common universal values, which will become the basis for the formed monoculture. The European attitude towards death is focused on the reconciliation of man with death, the consolation of the dying, and his relatives. Death is seen as the ending of earthly life. Death in Russian culture is conceived and perceived by salvation and faith in God; seen as an element of mentality and as an integral part of the spirituality of man and society. In contrast, American (Western) culture criticizes the afterlife. Death is seen as the total destruction of man's personality, as a defeat and a constant reminder to humanity of the limitations of power over nature. Globalization processes require a review of existing values and the creation of a new type of culture with a sustainable and unified system of values at the global level.
\end{abstract}

Keywords - globalization, cultural diversity, death, philosophy, monoculture, culture, language, values

\section{INTRODUCTION}

Globalization dates back to the 1990s. It proclaims the thesis of a world without borders, a world as a "global multipolar community of nations and states". In spite of the ideal model of the globalization planetary system, there are obstacles to the realization of the intended goal of cultural diversity, which includes a diversity of cultural, ethical norms and values.

The state of contemporary culture has encouraged scientists to deal with issues related to the diversity of cultures and research on common grounds for the functioning and development of a unified culture within the framework of globalization. On the one hand, scientists talk about the formation of a new world society infrastructure, the reconstruction of economic, political and social systems, world religions, local civilizations and national cultures. On the other hand, we have seen an increase in intercultural interactions and the emergence of English as a global language.

Cultural diversity distinguishes one nation from another and determines the diversity and multidimensional cultural space of the world. Intercultural cooperation may cause many problems related to the full integration of cultural space. One such problem is language. According to D.S. Likhachev, the wealth of language is the concentrator of culture - the culture of the nation and its implementation in different levels of the population [1]. In the process of communication, communicants who are subjects of the same culture at an unconscious level and/or consciously read the culture code and also recognize it in the process of reading. Culture as a continuous process, contributes to a new configuration of values and attitudes, which acquire a new pragmatic meaning and adjust culture to a new way [2]. Similar processes are common to language. In the process of continuity of traditions, value orientations and attitudes, it plays a huge role, reflects the phenomena of culture recorded in it. Language conveys to members of the language community a spiritual vision and thinking [3].

Globalization will lead to a clash of cultures, a culture with the greatest "absorbing potential" to maintain its own identity, changing its own linguistic structure, enriching its conceptual sphere and becoming a monoculture.

The phenomenon of death becomes the point of contact of the formation of a unified attitude to death for most active communities in the modern world of cultures. Consequently, the study of attitudes towards death in different cultures solves the problem of universal and global values, which is relevant in the context of globalization. Through the phenomenon of death, it becomes possible to study the mechanisms of influence on the axiosphere of a certain culture.

The presented article reveals the phenomenon of death in European, Russian and Western (American) cultures. Philosophical and cultural reflection is formed on the basis of centuries-old experience of the people and includes a certain value attitude. Most important are questions about the meaning of human existence, the essential nature of death, whether it is the end of individual existence. The study of these issues sheds light on the meanings attributed to it in a certain culture.

\section{MATERIALS AND METHODS}

The material for the study was philosophical works of famous American, Russian and European philosophers. In the submitted article we used general methods: inductive, deductive, conceptual methods, comparative and discursive methods. Linguoculturological methods: a method of cultural interpretation, linguoculturological analysis of philosophical texts. 


\section{RESUlts}

\section{A. Death in European Culture}

The study of the phenomenon of death allows one to characterize the latter as a set of principled attributes, which emphasizes its paradoxical nature.

In a sense, death is the termination of the life of a living being, the starting point of the development of selfconsciousness, the understanding of man of his identity. The fact of finite existence contributes to the fact that man begins to value every moment of his existence. The thought of own mortality distinguishes man from other living beings.

Some scientists propose to define death as an extreme degree of nonfiction. Death is nothing, but we will all die, and this last truth is nothing. It's nothing for the living because they're alive and nothing for the dead because they're gone. It is necessary to abandon images of death and fear of it. Humanity should learn science to live so it is necessary to think about death taming and accept it.

Mankind has been trying for centuries to explain the category of death outside the field of interpreting biological knowledge about it. Most important are questions about the meaning of human existence, the essential nature of death, whether it is the end of individual existence. The study of these issues sheds light on the meanings attributed to it in a certain culture.

The first recorded attempts at interpretation are found in the religious cultures of the ancient world. Each culture reflects the concept of death in its own way. The earthly existence of ancient Egyptians was intended to prepare for the afterworld - life after death, a reflection of the attitude to death is the construction and decoration of tombs, the art of embalming. In Mesopotamia, the epic nature of attitudes towards death is becoming widespread. In India, Buddhism proclaims a tragic attitude towards the end of existence. The birth and prosperity of Zoroastrianism in Iran and Daoism in China are evidence of the spiritual development of an exacerbated sense of personal being.

In ancient Greece, the problem of thinking about death became a subject of debate among philosophers. Socrates believed that "those who are genuinely devoted to philosophy are occupied with one thing - dying and death". Socrates philosophy implies a reasonable understanding of the subject under consideration wise people at death will grieve, and rejoice in this case is characteristic only stupid. Socrates emphasizes the knowledge by which a person after death appears before good lords, gods, so should not be grieved, for "the dead exist and that the good of them is much better than the evil". There is a thread of Socrates's moral concept: knowledge is the greatest good, thanks to the first man becomes virtuous. It is receiving the greatest benefits that allows man to meet death with dignity: man will meet death with courage and hope for the coffin to acquire the greatest benefits.

Death itself, according to Socrates, is interpreted as the recovery of the soul. The soul, remaining in the body is mixed with evil. By death, through removal from the senseless body, the soul becomes pure, "for unclean to touch pure is hardly allowed". The thesis about the immortality of the soul states that the soul exists before birth, and for birth and entry into life the soul had to emerge from death and from the state of stillness, it does not need to exist after death for revival. The soul is similar to the immortal, intelligent, not destroyed, always identical, existing always in the same way; The body, on the other hand, is like a human, mortal, not mind-breaking, decaying, once non-existent in the same way [4]. After death, the body of a person is called dead, the soul is completely immortal and is not subject to death.

Epicurus, exploring questions of life and death, writes that death is nothing. Life is filled with good or bad sensations, and death is deprivation of sensations. He held faith in the absence of fear of death, because it does not really exist, man does not face it, and therefore there is nothing to fear it. When death occurs, man is no longer present.

The teachings of ancient Greek thinkers are opposite but they are united by a truly Greek rational grain in the very approach to the fact of death. At the time of death, ancient Greek philosophy seeks support for man in the immortality of the soul, in denying the fear of death and death itself.

The teachings of ancient Greek thinkers are opposite in content, but they are united by a truly Greek rational grain in the very approach to the fact of death. At the time of death, ancient Greek philosophy seeks support for man in the immortality of the soul, in denying the fear of death and death itself.

Socrates's concept of the immortality of the soul and the sinfulness of the body is reflected, perceived by Christianity, and becomes the defining tradition of the spiritual life of Europe.

The philosophical-theological Christian approach is focused on the reconciliation of man with death, the consolation of the dying and his relatives. The relocation of souls, death, the afterlife is a source of reflection, philosophical conclusions. Gregory Nisskiy, reflects on the unacceptable relocation of souls and the separation of the soul from the body. For a Christian, the claim to relocate souls is unacceptable, but also contrary to the obvious distinction of animal species. Let us assume that any soul can revive a body - means that: all bodies - the human race, plants and animals have the same nature. In his opinion, the soul cannot exist before the body, cannot be created after the death of a person, for the body without the soul is a corpse. The existence of a body is impossible without the presence of a soul. Therefore, it is necessary to note that the soul and body be created by God at the same time. The soul of man after death does not separate from the atoms of its components. Let them be "scattered, but the soul is intangible and therefore can remain connected to these elements in some state of dispersion and mixing".

It is worth noting that within Christianity there are differences in attitude towards death. In Catholicism, a man is aware of death and must live in the face of death, within his existence in anticipation of going out without suppressing his knowledge of death. Death from the position of Catholicism, 
return to God. Many beings who form the universe come from God, stay in God and return to God. The return to God is indicated by the movement of divine love contributing to the reversal of the hierarchy of living beings, which ultimately leads to unity. This call manifests itself in the need of all beings for God, which Eriugena calls "no formality." It is defined as a movement from nothingness to being. The universal return is linked to the return of man, and it begins at the hour of greatest decay that human beings could achieve as a result of death. As a result of sin, man became like animals, obeyed passions, pain and death. At the time of death, the soul is separated from the body, which itself disintegrates into constituent elements and dissipates on the ground: but precisely because the circulation of creatures is a river whose course is never interrupted, the last moment of "separation" creates something united with the first moment of "analysis." Death becomes the beginning point of man's return to God the first stage. The second stage is the resurrection of bodies, which will be the result of the joint action of nature, God and grace. In the third stage, the bodies of all Christians connect with the souls from which they came out due to division. This reunion includes several stages of return, the opposite stages of care: the body will become life; life will become feeling; feeling - reason. The mind is pure thinking. In the fourth stage, the human soul will merge with its root cause, or idea, and along with the soul will merge the body it has absorbed. All beings in thinking in their mind-setting form will be returned to God. Their final return is the fifth stage of a return to God [5]. Eriugena writes, gay is the remainder of pagan superstitions. There will be no other pleasure, except eternal life, eternal life is a knowledge of the truth. That knowledge of the truth will be the only bliss.

Orthodoxy interprets death as the separation of the soul from the body and clarifies that death is the devil's victory in earthly life. Death is an evil of chance, invading our nature through sin and the crime of the law of God. Life is given to man as a sacrament of communication with God, the horror of death lies in the separation of man from God [6]. Victory over death ensures the coming resurrection of the dead when souls reunite with bodies. As a result, which must completely end the terrible rule of death and disappear the most recent traces of it. The consciousness of the immortality of the soul occupies an important, central place in the system of Orthodox teaching.

The development of a philosophical-religious Christian approach is related to the theme of death and immortality. The Old Testament did not elaborate on the idea of divine revelation about the fate of the dead, although grounds for hope for immortality (overcoming death) were present. Death in the Old Testament is perceived as an annex to the people, inclusion in their forefathers, and earthly life is understood as a journey to the fatherland of the best, heavenly. The New Testament defines death as a great sacrament, cherished for everyone, in which the complementary features are closely intertwined: the separation of the soul from the body connected by the will of God, occurring due to the original sin, as a result of which the body of man ceased to be intact. God created death, it is an unnatural, random phenomenon in humanity, a consequence of $\sin$ and retribution for $\sin$.
The existence of death is pronounced in the religious consciousness of a medieval man in direct connection with one's inevitable companions - a postmortem trial, a reward, paradise and hell, purgatory. Death becomes the ending of earthly life, bright and dark, tragic-solemn act of transition to another world. The afterworld attracted and frightened, promised eternal bliss and horrified eternal torment. Christianity did not deny fear of death; it is likely that this fear turned into fear of the judgment of God. The fear of death added fear of the world of the dead, real, as well as the world of the living.

Death in Renaissance philosophy takes on new forms of interpretation. F. Petrarch identifies the principles of philosophical study of the problem of death. He offers to live life fully, with patience, with disregard for brief life and with love for death, thus bringing death closer to face. The soul must not fear death, but must live a completed life, immersive in virtue, in memories of the past good and in hope for the future [6]. A man who lives with the thought of death, with the way of death includes death in the categorical series of Earth existence, joins death to each piece, a particle of life, filling them with the meaning of being.

Renaissance thinkers made attempts to "revitalize" human passions, feelings, freed existential states from the peripheral zone, and introduced them into the circle of philosophical understanding.

The philosophy of the European Enlightenment in the late 17 th century actively studied the problem of death in terms of deism and pantheism. Deism is characterized as a religiousphilosophical teaching of God as a creature who created the world, after the creation of the world, the movement of the universe is performed without his participation: neither miracles nor the message of his son to earth have to do with the world. The deistic approach proved that death is not retaliation for human sins committed, because man is by nature kind. There is no hellish muck and there should be no fear of death as a fact of the end of human life.

The opposite view was held by pantheists, who dealt with the identification of God with nature, with the whole universe. In particular, they denied God's transcendence and Christian understanding of death as a transition of immanent into a transcendent world. Pantheists have argued that God is dissolved in every particle of the world and that, man is kind from nature, his soul can be reborn several times [7].

The coming philosophical idealism of the 18th and 19th centuries does not simplify the paintings of the philosophy of being and death. The philosophy of life declared the cult of eros and death. Eros and death is the closing moment of wakhic delight and final fusion with the dark foreground of being. A. Schopenhauer in his works pointed out that being is a dark element of the irrational will of man himself, the way out for man from endless running through the circle of lust and suffering of unenforceable will in refusing to participate in the cycle of life is immersion in the nirvana of nothing [8]. Death has two functions: to rid man of suffering, routine life and the purpose of human life. The philosophical thinking of death significantly influenced the culture of the 19th and 20th centuries F. Nietzsche worked on the current problems of 
justification of death from mercy, justification of suicide and questions of dialectic of compassion. Unlike A. Schopenhauer F. Nietzsche fully embraced the life element of unchecked power, throwing away as a disastrous illusion faith in the potty world and moral values that constrain the energy of a strong individual - a superhuman [9].

The philosophy of idealism changed to that of existentialism in the first half of the 20th century. In terms of existential philosophy, man experiences his death as the religious sacrament of transcendent and immanent. Death acts as something absurd for an ordinary person. Absurd originates not from the senseless existence of man, but from the concealment of the meaning of being from man. Life is a less significant event in life than death. Death is the last boundary of human life, the ultimate phenomenon of life. Life is limited to life, it becomes finite but limitless, death becomes the meaning of life, death is individualized. The end of a man's life is like his life; all individual life was the preparation of that end. The hidden uncertainty of death, according to $\mathrm{M}$. Heidegger, is defined as follows: death as the end of a presence is the most its own, unquestionable, reliable and as such an uncertain, unenforceable possibility of presence. As the end of presence death is in being this substantial by its end [10].

The shift of the philosophical paradigm in the second half of the 20th century contributed to the emergence of a new direction in philosophy. This direction was called - historical and cultural. The framework examined the specific features of thinking about the phenomenon of death depending on the specific stage of society's development. Representatives of the historical and cultural direction begin to explore the phenomenon of death through different prisms of human life, for example, through love, happiness and thought. It should be noted that the results of research allow one to talk about the subconscious side of death. In the 20th century, death occupies the periphery of the consciousness of man and society. Some questions after-death of a person are put first, it is obituary, funeral; immortality becomes fiction [11]

M. Foucault writes that the very being of man is limited by body, desire and language. Given the thought of being closed within certain boundaries, note that the limb of human being is open to the positivity of any particular limit. Death, which reduces the hours of our existence synchronously, is also a fundamental death within the boundaries of which man experiences empirical existence. The body, like the soul, is in a continuum called infinity. Note that $M$. Foucault characterized the value of death as "death alien, but expected as his own" [12]. It becomes a kind of mirror of life, a reflection of a certain episode of culture at a certain period of time.

\section{B. Death in Russian Culture}

The particular interest is the study of the issue of death in Russian culture. The national feature of Russian culture and philosophy can be called its appeal to man. Russian religiousidealistic anthropology assesses the essence of man, relating him to God, focuses on the world of values of the afterlife. Russian positivism defines the essence of man as a specific- historical set of social connections. The focus on Earth ideals, on the unconditional authority of social determinations contributed to the loss of attention to the anthropological problem.

The formation of philosophical thought of ancient Russia, the mythology of ancient Slavs and first of all its idea of community were provided. Understanding the world as "We are a fusion of material and ideal, personal and social," single and common proved stable and formed the worldview potential of Russian philosophy. In Russia, unlike Europe, the attitude towards death has always remained traditionally Christian. Death is perceived by salvation and faith in God.

Opposition to Orthodoxy and paganism led to the "obfuscation" of Christianity and the preservation of the ideas of the national religious heritage in Christianity. In the 11th centuries, there was a Mystic-Christian concept, considering the problem: if salvation is possible through the understanding of divine truth, while it is possible to understand this truth. Truth can be achieved by prayer and humility.

Philosophical thought of medieval Russia is based on a position of complete ratio of human and divine. Human is regarded as human, divine as divine, and divine in human is a condition for salvation [13]. In this case, divine and human gain separate autonomy.

A person can be defined as a nature dual, conditioned by the presence of a soul and body. The body consists of senses and minds; the latter possesses the whole body. God endowed the human body with soul. At the level of the soul, through the idea of salvation man is connected with God.

Faith in the cognitive power of the human mind brought Russian philosophy closer to the rationalist traditions of European philosophy. When considering the problem of the relationship of soul and body, the essence of man is not investigated, considering the fact of existence in man of soul and body, eternal and temporary proven.

For centuries, the focus of philosophy has remained the problem of man and the meaning of being. Philosophers looked at the relationship between soul and body, feeling and mind building on recent advances in physiology, medicine. Two polar views of death emerged in this direction of philosophical thought. Y. P. Kozelski's idealistic view of the relationship between body and soul was rejected because of its insolvency. The materialist approach of A. N. Radishchev, M. V. Lomonosov lies in the contradictions between the scientific empirical evidence of immortality and its probabilistic character, immortality remains only to be believed [14].

Russian philosophy aims to provide anthropological proof of God's existence. God exists in the super-sensitive world of the human person. Man must strive for self-improvement in order to realize himself as an instrument of God, to merge with him, thus to receive salvation from death, social injustice. The active position of the creator N. Fyodorov explains the attempt to connect anthropism and cosmism. Man is cosmically focused on preserving life on Earth. Man in the name of overcoming death should go into space. The main task of man is to overcome death and master the "life creation," the resurrection of the dead. The main task of resurrection is self- 
recovery of nature and revival of living people, preservation and maintenance of living life [15]. Rational grain in combining the ideas of cosmism and anthropology $\mathrm{N}$. Fyodorov sees in overcoming diseases and epidemics, combating old age, fighting hunger and replacing body organs.

Vl. Solovyev criticizes the "Common Case Doctrine". N. Fedorov notes that resurrection should be only religious, and not scientific. He writes that man and mortal are synonymous words. Man takes the word mortal as "a meagre reproach to himself, man conscious of the inevitable death as an essential sign of his existence, strongly does not want to tolerate it, does not calm down in this consciousness of its inevitable".

The salvation of the soul he sees in a real resurrection. As a result, evil (extreme evil - death) gets its meaning and the explanation of its being is that it serves to realize and enhance good. Vl. Solovyev believed "if death is stronger than death life, then resurrection into life eternal is stronger than both. The kingdom of God - the kingdom of triumph through the resurrection of life - in it the real, final good" [16].

In the 19th and 20th centuries, there was a need for a new indivisible world view, harmoniously combining orientation to the various beginnings of being. Philosophers began to realize that the solution of worldview problems is impossible without the study of man, his essence and existence. At the same time, the idea of a crisis of culture and worldview in both European philosophy and Russian is beginning to be argued. The tragedy of being is reflected in philosophical works and literary works. The rapid development of industry contributed to the mechanization of spirit, self-condemnation, which ultimately led to the loss of man's identity. The turning point of culture and consciousness marked the beginning of a new direction - the Russian religious renaissance [V. Rosanov]. V. Rosanov proposed a new interpretation of the life-creative philosophy of life, the so-called religion of gender.

The teaching of Russian cosmism played an important role in resolving the question of death. Within cosmism, death is viewed in the context of immortality and is related to man's desire for perfection, to transcend the individual's own limits, and to overcome himself. Anthropocosmic worldview emphasizes the immortality of man provided that his creative activities are expanded. According to the theory of V.I. Vernadsky, the death of a person becomes not inevitable. The development of human thought contributes to the development of the riches of the planet, in case of exhaustion - mankind will turn its eyes to space.

The 20th century was marked by the emergence of a new direction in Russian cosmism - the emergence of sophiology. The main task was to study the connection between the material and spiritual component of human existence and to justify the connection between the world of heaven and earth. This task was performed by spiritual philosophy or the philosophy of worship. According to which culture, first of all, is the fight against death. Culture is access to the disclosure of values and is accepted as unconditional, so it is the subject of faith. The belief defines a cult, the cult outlook from which follows culture. In which function, there are values fixed in the cult and enters into a fight against death.

\section{Death in American Culture}

Modern American (Western) death philosophy takes a clinical approach examining the problems of human attitudes to death within palliative medicine.

Philosophical problems of an attitude to death in modern society turn out to be in line with social practices. Alienation from the fundamental biological aspects of existence finds a vivid embodiment and expression with respect to the basic life triad: birth, sex, and death.

Z. Freud, researching the ideas of F. Nietzsche and the School of Existentialism, concluded that death is a complex phenomenon that includes different value attitudes to human death depending on the perception of one's own - alien death.

In Western philosophy, there are theories showing that biological death is the beginning of the existence of consciousness in a new form. R. Moody writes that the dying (who experienced clinical death), whose soul, consciousness separated from the body, felt no bodily shell, perceived themselves as "pure consciousness" or as a clot of consciousness [17].

The question of the relocation of the soul to another body after death remains unresolved. Clinical evidence describes a "new body" as an area of experience related to death and notes its weightless property, interpreted as a sense of flight, a sense of weightlessness.

We note that Western philosophy criticizes religious teaching about the afterlife. Faith in conscious life after death and in the postmortem path of the soul is considered a manifestation of primitive fear and superstition of a person deprived of the advantage of scientific knowledge. Faith in the afterworld is part of our religious tradition, but for the Western person religion has completely lost its inherent vitality and importance. In many cultures, the provisions of cosmologies, religious and philosophical systems are still preserved, according to which death is not the last point, life in the afterlife continues, only takes a slightly different form.

In Western culture and philosophy, death is seen as a transformation, as the total annihilation of an individual, as a defeat, a painful reminder of the limitations of man's power over nature. A terminally ill and dying man in American culture is considered a loser, and so does he himself. Modern medicine seeks to defeat death or delay its arrival. In the struggle for mechanical continuation of life, little attention is paid, as the patient spends the last days, to his philosophical, psychological and spiritual needs. What is directly related to the basic principles of bioethics, especially the principle of respect for the personality of man, that is, the inadmissibility of imposing religious, philosophical views? The elderly and dying are removed from the family and from everyday life, placed in hospices.

E. Kübler-Ross believes that death is perceived by man as tragedy, misfortune, so it is necessary to prepare for it in advance. By training, she understands the relief of the dying's emotional state. Dying is as much a full part of being as childhood [18]. 


\section{References}

European philosophy determines death as termination of a man's life, as a sad finish of his or her life. Death was regarded as the unequivocal and permanent end of existence. In the face of death, a person acquires the meaning of life. At the time of his death, there is liberation from the false goals, ideas, motives and activities that fulfill his life.

The main feature of Russian philosophy is the consideration of death from the position of "Man: God" as interconnected and mutually reinforcing components. Death is considered as a cultural constant of Russian society, an integral part of the mentality of man and society and as an element of the collective representation of society.

Modern achievements of American medicine, philosophical point of view are unable to completely alleviate the mental suffering of the dying. The taboo of death as something alien to human being has now been removed, but it represents a constitutive part of human life itself.

The results of modern western clinical studies of dying and death more confirm the general provisions of eschatological systems of eastern religions and philosophies.

\section{CONCLUSION}

The world community is faced with the problem of the lack of a clear configuration of the phenomenon of death in a globalizing world culture. The phenomenon of death is the basic phenomenon of the system of values in culture and takes an active part in the formation of moral attitudes. In the context of globalization, the hierarchy of values varies from the dominance of spiritual values to the prevalence of material values.

The question of the prevalence of one type of attitude to death over others by virtue of the lack of integrity of a single value system remains controversial. Culture, 1996, p. 230-232.
[1] D. Likhachev, Conceptosphere of Russian Language, vol. 52, No. 1. Moscow: IAN SLA, 1993, pp. 3 - 9.

[2] V. Telia, Russian phraseology. Semantic, pragmatic and linguoculturological aspects. Moscow: School Languages of Russian

[3] J. Weisgerber, Native language and spirit formation. Moscow: Librocom Book House, 2009, pp. 130-132.

[4] Plato, Fedon. M: Thought, 1999, pp. 146-147.

[5] E. Gilson, Philosophy in the Middle Ages: From the origins of patristics to the late 14th century. Moscow: Republic, 2004, pp.53-56.

[6] A. Gagarin, Existentials of human being: loneliness, death, fear. From Antiquity to New Time. Yekaterinburg: Ural University Publishing House, 2001, pp.207, 239.

[7] B. Spinoza, Selected Works, vol. 2. Saint Petersburg: Science, 1999.

[8] A. Schopenhauer, Selected Works. Moscow: Enlightenment, 1992, pp.629-632.

[9] F. Nietzsche, Zaratustra. Moscow: Eksmo, 2011, pp.190-194.

[10] M. Heidegger, Genesis and Time. Moscow: Ad Marginem, 1997.

[11] F. Aries, Images de l'homme devant la mort. Moscow: ProgressAcademia, 1992, pp.30-32.

[12] M. Foucault, Words and things. Archaeology of Humanities. St. Petersburg, A-cad, 1994, pp.336-342.

[13] B. Emelyanov, Three Centuries of Russian Philosophy (XVIII-XX centuries). Yekaterinburg: Ural. University, 1995, pp.17-24.

[14] V. Tatischev, Talk about the benefits of sciences and schools. Moscow: Book on demand, 2011.

[15] N. Fyodorov, Philosophy of Common Case. Moscow: Book on Demand, 2012.

[16] V. Soloviev, Selected Works. Moscow, Soviet Russia, 1990, pp.226230.

[17] R. Moudi, On the other side of death. Moscow: Old Letavre, 1994, pp. 65-67.

[18] E. Kübler-Ross, On Death and Dying. Kiev: Sofia, 2001. 